\title{
PELAYANAN DAN BAKTI SOSIAL PASCA BANJIR DI KOTA TANJUNGPINANG: SEBAGAI WUJUD RASA KEMANUSIAAN
}

\author{
Fransiskus Irwan Widjaja1), Talizaro Tafonao2), Benteng Martua Mahuraja Purba3), \\ Sabar Manahan Hutagalung ${ }^{4)}$, Candra Gunawan Marisi ${ }^{5}$, , Fredy Simanjuntak ${ }^{6}$, Selvyen \\ Sophia ${ }^{7)}$, Efvi Noyita ${ }^{8)}$ \\ 1,2,3,4,5,6,7,8) Sekolah Tinggi Teologi Real Batam \\ 1)irwanwidjaja.fiw@gmail.com, ${ }^{2}$ talizarotafonao@gmail.com, ${ }^{3)}$ bentzmm@gmail.com, \\ 4)sabarmanahan85@gmail.com, ${ }^{5}$ candragunawan512@gmail.com, 6)fredygrace@gmail.com, \\ ${ }^{7)}$ selvinchute99@gmail.com, ${ }^{8)}$ efvinoyitapermata@gmail.com
}

Histori artikel

Received:

17 Februari 2021

Accepted:

10 Maret 2021

Published:

19 April 2021

\begin{abstract}
Abstrak
Tujuan dari pengabdian ini adalah memberi dorongan secara moral dan psikologi lewat pelayanan dan bakti sosial kepada masyarakat yang sedang mengalami musibah. Pelayanan dan bakti sosial yang dilakukan oleh tim didasarkan pada rasa kepedulian terhadap masalah yang dialami oleh masyarakat/mitra. Situasi masyarakat saat itu masih dalam kondisi bingung dan takut karena situasi yang masih mencekam. Tetapi dengan hadirnya para tim pengabdian di lapangan/lokasi sangat membawa pengaruh positif kepada masyarakat melalui Aktivitas yang dilakukan. Artinya bahwa masyarakat yang sedang mengalami musibah sangat perlu ditolong dan diperhatikan sebagaimana ulasan dalam artikel ini. Bentuk dan metode kegiatan yang dilakukan adalah pelayanan dan bakti sosial dengan pendekatan sosiologis secara humanis. Hasil dari kegiatan ini dapat dirasakan oleh masyarakat sekitar $85 \%$. Hal ini nampak pada Aktivitas yang telah dilakukan oleh tim pengabdian masyarakat serta apresiasi dari seluruh masyarakat dan pemerintah berdasarkan penjelasan dan uraian dalam tulisan ini.
\end{abstract}

Kata-kata Kunci: pelayanan dan bakti sosial, kegiatan kemanusiaan 
Abstract. This service aims to provide moral and psychological encouragement through social service and service to people experiencing a disaster. The team's social services and services are based on a sense of concern for the community/partners' problems. At that time, the community's situation was still in a state of confusion and fear because of the tense situation. But the presence of the service team in the field/location has a very positive influence on the community through the activities carried out. It means that people experiencing disaster need to be helped and given attention, as reviewed in this article. The forms and methods of activities carried out are social services and services with a humanist sociological approach. The results of this activity can be felt by the community around $85 \%$. This can be seen in the activities that have been carried out by the community service team as well as the appreciation of the entire community and government based on the explanations and descriptions in this paper.

Keywords: service and social service, humanity activities

\section{PENDAHULUAN}

Cuaca yang ekstrem disertai dengan hujan dan angin kencang pada tanggal 1 - 2 Januari 2021 mengakibatkan terjadinya banjir yang melanda sejumlah wilayah Tanjungpinang dan Pulau Bintan. Ada pun titik yang terdampak banjir dan longsor, yaitu daerah Lembah Purnama, Perumahan Sri Andana, Bilangan Jalan Hanjoyo Putro Batu 8, Jalan Hang Lekir Perum Elang Semesta Batu 9, Bangunsari KM 11 Gg Perkutut, Green Camp Jalan Lembah Merpati, kawasan Taman Seraya Batu 9 dan lokasi sekitaran KPU Tanjugpinang serta perumahan Hangtuah Permai KM 12.

Berdasarkan pantauan para Petugas mengatakan bahwa ketinggian banjir sangat bervariasi mulai dari 2 - 3 meter. Akibat hantaman dari banjir ini membuat sebagian pemukiman warga longsor sehingga warga harus mengungsi ke tempat lebih aman dan sebagian besar warga tersebut terjebak banjir karena rumah mereka terendam banjir. Banjir ini menimbulkan beberapa kerugian yang dialami oleh masyarakat/mitra, yakni masalah kesehatan, kerugian ekonomi, sulitnya dapat air bersih, dan infrastruktur rusak serta sulitnya mencari makanan hewan peliharaan. Tidak hanya itu, menurut Rahayu bahwa banjir dapat merusak permukiman penduduk, sarana dan prasarana dan menghambat transportasi darat (A \& Rahayu, 2014). Selain itu, menurut hemat Murdiyanto mengatakan bahwa akibat hadirnya bencana alam dalam masyarakat sangat berdampak besar kepada manusia, yakni menimbulkan korban berupa perorangan, keluarga atau kelompok masyarakat yang menderita baik secara fisik, mental, maupun sosial ekonomi serta mengalami hambatan dalam melaksanakan tugas kehidupannya (Murdiyanto \& Gutomo, 2015).

Berdasarkan Gambar 1 dapat memberi informasi bahwa tragedi ini mengisahkan berbagai pilu mendalam bagi masyarakat yang mengalaminya seperti kehilangan tempat tinggal, pekerjaan, barang-barang berharga serta Aktivitas di luar rumah menjadi lumpuh total sehingga untuk memenuhi kebutuhan keluarga selanjutnya sangat terganggu. Sriharini mengamati bahwa hari-hari ini Indonesia seakan-akan tidak pernah terlepas dari kejadian bencana alam tidak sedikit menelan korban jiwa bahkan setiap tahun tercatat ribuan orang meninggal dunia, luka-luka, dan mengungsi dari tempat tinggalnya, serta banyak lagi 
kerugian-kerugian lain yang diakibatkan oleh bencana. Berbagai fasilitas umum dan hasilhasil pembangunan yang dilaksanakan selama bertahun tahun roboh dan rusak sehingga memerlukan biaya perbaikan yang cukup banyak (Sriharini, 2010).

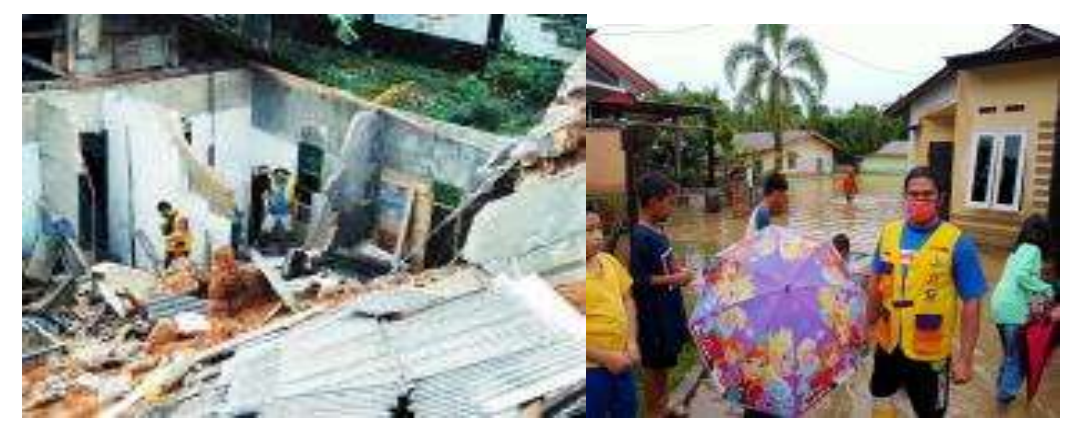

\section{Gambar 1. Foto tim yang sedang melihat kondisi rumah warga}

Dengan situasi seperti ini, masyarakat sangat membutuhkan kepedulian dari berbagai pihak. Dalam kajian yang dilakukan oleh Widayanti menjelaskan bahwa dalam upaya meringankan beban para korban banjir ini, maka menuntut sikap tanggap dan peduli dari berbagai pihak untuk berpartisipasi demi rasa kemanusiaan (Widayanti, 2016). Hal ini juga tertuang dalam Undang-undang Nomor 24 Tahun 2007, bahwa tujuan dari penanggulangan bencana adalah memberikan perlindungan kepada masyarakat dari ancaman bencana serta mendorong semangat gotong royong, kesetiakawanan dan kedermawanan dari masyarakat. Itulah sebabnya peran pemerintah sangat penting dalam penanggulangan bencana alam karena menyangkut keselamatan dan keamanan bagi setiap orang (Suryadi, 2020). Oleh karena itu, Widayanti mengaskan bahwa wewenang pemerintah sangat perlu mendorong potensi sosial masyarakat, agar masing-masing warga memiliki sikap sosial positif bagi masyarakat yang sedang menerima musibah (Widayanti, 2016).

Berdasarkan kondisi dan situasi tersebut, maka Team REAL CARE dan GBI Peduli bergerak mengadakan aksi pelayanan dan bakti sosial (Gambar 2). Tujuan dari kegiatan ini untuk meringankan beban masyarakat yang mengalami musibah tersebut.

Pelayanan dan bakti sosial yang dilakukan oleh tim salah satu wujud kepedulian terhadap masyarakat/mitra sebagaimana ulasan sebelumnya. Bagi tim kegiatan ini tidak mudah untuk dilaksanakan karena dilakukan dimasa pandemi, tetapi demi rasa kemanusiaan para tim tetap melakukannya dengan mengikuti protokol kesehatan. Imamsari melihat hal ini bahwa partisipasi dari masyarakat sangat berperan penting dan paling efektif dalam mensukseskan upaya penanggulangan banjir, karena masyarakat sendirilah yang paling tahu kebutuhan mereka (mitra) (Imamsari, Triastuti, \& Wijianto, 2017). Aktivitas yang dilakukan oleh tim pada kegiatan ini diuraikan pada pembahasan berikutnya. Tujuan dari pelayanan dan bakti sosial ini adalah memberi dukungan secara moral, pelayan kesehatan serta bantuan berupa keperluan sandang dan pangan pada warga masyarakat yang terkena 
dampak banjir. Targetnya dalam pelayanan dan bakti sosial ini adalah masyarakat/mitra yang mengalami musibah dapat bangkit kembali dan serta berAktivitas seperti semula. Dengan tercapainya target tersebut maka persolan-persolan yang dialami oleh masyarakat/mitra dapat teratasi dengan baik. Dengan melihat hal-hal seperti itu, maka tujuan dari kegiatan pengabdian masyarakat ini adalah memberi penguatan, dorongan secara moral dan psikologi lewat pelayanan kesehatan dan bakti sosial kepada masyarakat yang mengalami musibah banjir. Manfaat dari kegiatan pengabdian ini: 1) memulihkan kondisi kesehatan warga masyarakat yang terkena dampak banjir 2) mengurangi sedikit beban pikiran dan kekurangan dari warga masyarakat akibat dampak dari banjir 3) membagi suka dan cita bersama civitas akademika Sekolah Tinggi Teologi Real Batam.

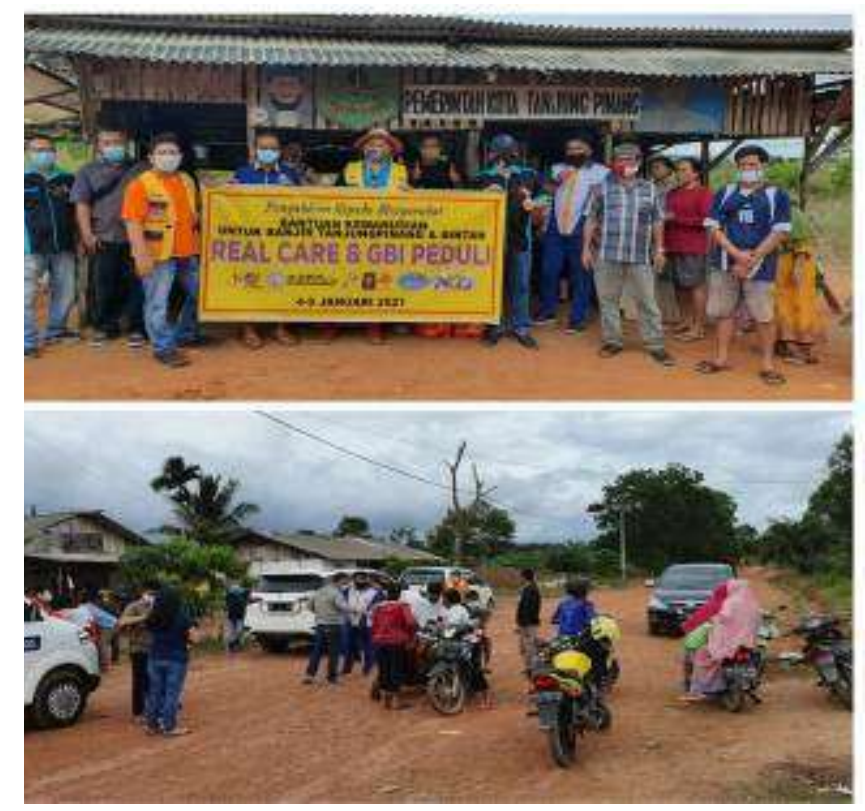

Gambar 2. Foto Tim yang Sedang Menuju Lokasi Korban Banjir

\section{METODE PELAKSANAAN}

Metode dalam penulisan artikel ini adalah metode kualitatif. Menurut Sugiyono mentakan bahwa metode penelitian kualitatif tidak menggunakan populasi karena tipe penelitian kualitatif ini berangkat dari kasus tertentu yang ada pada situasi sosial tertentu dan hasil kajiannya tidak akan digeneralisasikan ke populasi, sedangkan untuk penelitian kuantitatif menggunakan populasi atau sampel. (Sugiyono, 2015). Selanjutnya metode kualitatif adalah jenis penelitian yang temuan-temuannya tidak diperoleh melalui prosedur statistik atau bentuk hitungan lainnya (angka), melainkan dari data-data yag diperoleh dan yang dikumpulkan dengan mempergunakan beberapa pilihan sarana seperti wawancara, dokumen, buku, kaset vidio, foto-foto dan data sensus (Strauss \& Corbin, 2003). Metode pendekatan yang digunakan dalam penelitian ini adalah sosiologis. Dalam hal ini 
pembahasan lebih difokuskan pada penyelenggaraan pelayanan dan bakti sosial. Informasi yang didapatkan oleh tim dalam pengabdaian ini lebih banyak didapat dari masyarakat itu sendiri berkaitan dengan persoalan yang mereka alami saat itu. Spesifikasi dari penelitian ini adalah deskriptif, dimana penelitian ini dapat menggambarkan suatu keadaan objek. Penelitian deskriptif menurut Notoatmojo adalah "suatu metode penelitian yang dilakukan dengan tujuan utama untuk membuat gambaran atau mendeskripsikan tentang suatu keadaan secara objektif" (Notoatmojo, 2005).

Berdasarkan informasi dan kejadian di lapangan maka tim membuat suatu kegiatan sebagai sasaran. Sasaran pelaksanaan kegiatan ini masyarakat korban banjir yang ada di Kota Tanjungpinang dan sekitarnya. Dukungan dan kepedulian yang diberikan oleh tim pengabdaian dan mahasiswa Sekolah Tinggi Teologi Real Batam dapat memberikan dampak positif. Selain itu harapan tim pelaksana, dengan terlaksananya kegiatan ini, masyarakat dapat terbantu walaupun tidak dalam jumlah besar tetapi pelayanan dan bakti sosial ini bisa meringankan beban bagi masyarakat sebagaimana hasil dan penjelasan dalam artikel ini.

Pelayanan dan bakti sosial ini dilaksanakan pada tanggal $4-11$ Januari 2021 di wilayah Tanjungpinang dan Pulau Bintan. Metode pelaksanaan pelayanan dan bakti sosial ini dilakukan dengan mengumpulkan data dari dinas yang terkait mulai dari tingkat RT, RW, Kelurahan, Kecamatan sampai di tingkat Kota. Korban yang terdampak banjir saat itu sejumlah 1,493 orang dan 21 lokasi banjir. Berdasarkan data yang telah didapat maka para tim membagi tugas untuk melaksanakan seluruh kegiatan termasuk dalam penyaluran bantuan sosial baik berupa makanan dan paket sembako.

Setelah kegiatan ini dilakukan maka tim melakukan evaluasi. Evaluasi ini bertujuan untuk mengukur keberhasilan dalam melaksanakan seluruh kegiatan. Salah satu cara mengukurnya adalah setiap anggota tim/penanggung jawab kegiatan melaporkan kepada ketua tim pengabdian bahwa kegiatan telah dilaksanakan dengan baik sesuai dengan target yang sudah tetapkan. Dan hasilnya terbukti pada setiap kinerja yang sudah tercapai serta dalam penyaluran semboko semua warga telah menerimanya sesuai data yang ada.

Aktivitas yang dilakukan oleh tim disambut baik oleh beberapa unsur pemerintah setempat, seperti Bapak. Rukmono sebagai Ketua RT 01 RW 10, Kelurahan BT IX Tanjungpinang, Bapak. Safei Ketua RW VI. Kampung Kualalumpur, Kelurahan Kijang Kota, Bapak. Mungkir ketua RW. JL. Srikaton. Kampung Purwodadi RT 002 / RW 007, Tanjungpinang dan Sekretaris Lurah Tanjungpinang Barat. Dalam sambutan unsur pemerintah setempat, mereka sangat berterimakasih kepada Tim pengabdian Masyarkat dari Sekolah Tinggi Teologi Real Batam atas kepedulian dan dukungannya secara moral dan materi kepada masyarakat yang mengalami musibah. 


\section{HASIL DAN PEMBAHASAN}

Hasil

Kegiatan pelayanan dan bakti sosial dilaksanakan selam 8 hari dari tanggal 4-11 Januari 2021 ini ada beberapa hal yang dilakukan dan dihasilkan oleh tim pengabdian masyarakat, sebagai berikut:

1. Mengumpulkan dan menyalamatkan ternak masyarakat.

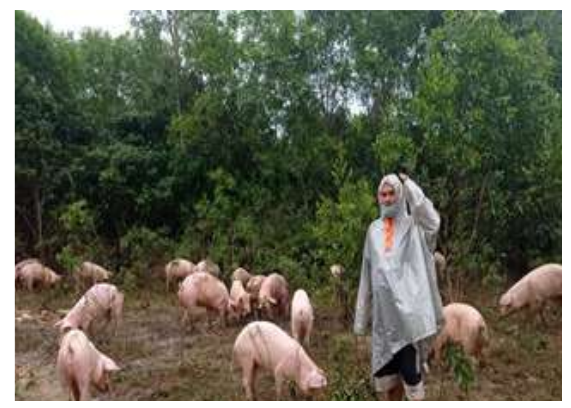

\section{Gambar 3. Foto Tim sedang yang Mencari Ternak Warga}

Dalam pengamatan para tim pengadian melihat bahwa kondisi Lokasi Peternakan warga saat itu sangat rendah sehingga air bisa mengalir dari berbagai tempat dan ditambah dengan air Laut yang sedang Pasang. Akhirnya ternak-ternak tersebut dapat keluar dari kandang. Selama banjir ada hewan peliharaan ini hanya makan seadanya karena pemilikinya ikut mengungsing ketempat lebih aman. Ternak-ternak yang ditinggal ini pada kelaparan dan berkeliaran dimana-dimana. Dengan hadirnya para tim di lapangan mengupayakan membenahi kandang-kandang yang sudah rusak dan mengumpulkan kembali ke kandang dan tidak berserakan di jalan karena sudah di buat pagar darurat serta diberi makan seadanya.

2. Melakukan pengobatan gratis

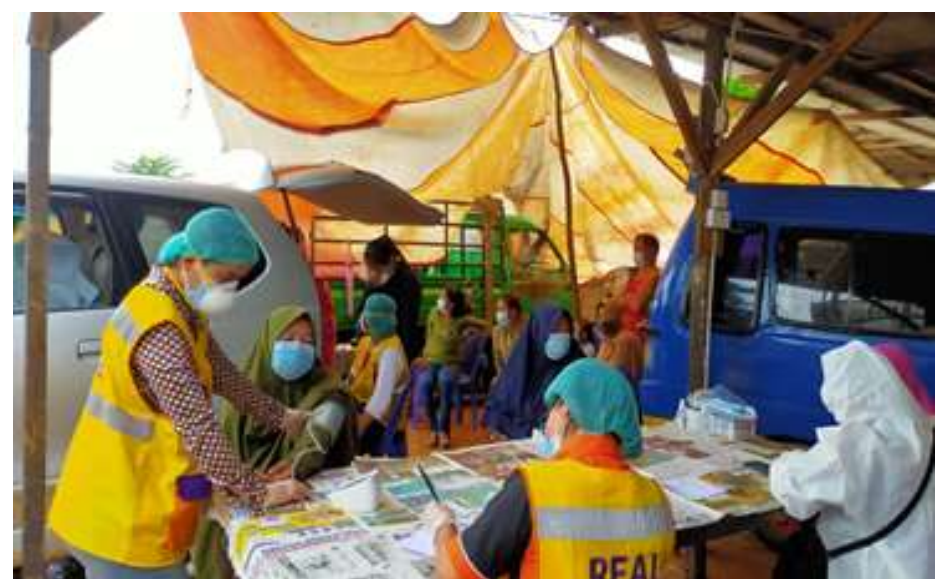

Gambar 4. Foto tim medis dan dokter pada saat memeriksa kesehatan masyarakat

Kegiatan pengobatan gratis dilakukan atas dasar kondisi/keluhan dari warga yang sedang mengalami batuk-batuk, pilek dan demam akibat pasca banjir, sehingga tim dari kesehatan dari pengabdian ini menghimbau kepada warga untuk memeriksa diri agar 
dilakukan pencegahan sejak dini, karena kita semua ada dalam situasi pandemi. Harapannya adalah semua warga mengalami musibah tetap sehat selalu.

3. Membuat dapur umum

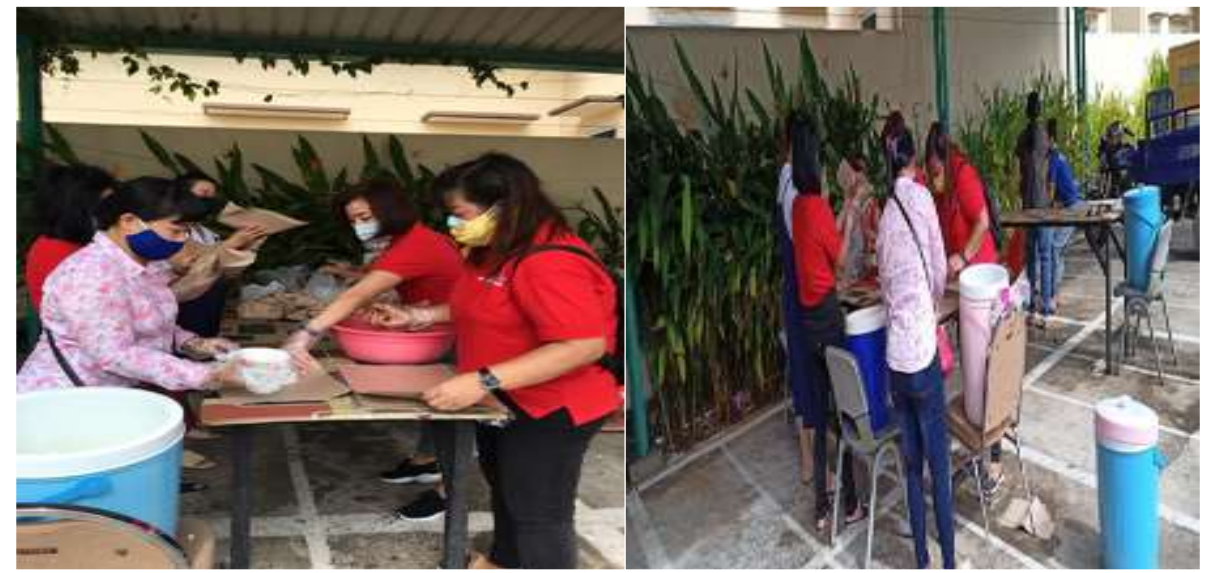

Gambar 5. Foto tim dapur untuk mempersiapakan makan warga

Tujuan dari dapur umum ini adalah untuk menyediakan makanan bagi warga yang telah mengungsi akibat dari musibah banjir. Hampir semua warga yang terkena banjir tersebut tidak dapat melakukan Aktivitas di rumah masing-masing termasuk masakmemasak, sehingga dengan kondisi seperti ini maka tim dari Care Real mendirikan dapur umum agar semua warga dapat makanan yang layak selama ada di tenda pengungsi sehingga terhindar dari sakit penyakit.

4. Menyiapkan air minum dan dapur air bersih tagana rajawali

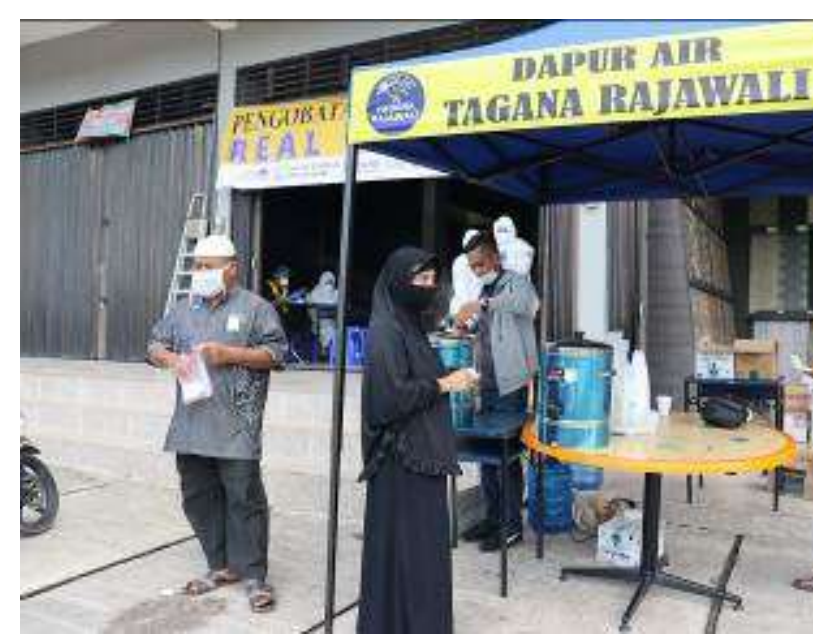

\section{Gambar 6. Foto tim menyiapkan air minum dan dapur air bersih tagana rajawali}

Salah satu kebutuhan mendasar dalam kehidupan manusia adalah air. Dengan melihat kebutuhan ini sebagai kebutuhan penting maka tim mendirikan dan menyiapkan air bersih bagi warga yang mengungsi dan yang datang untuk berobat. 


\section{Pembagian Sembako}

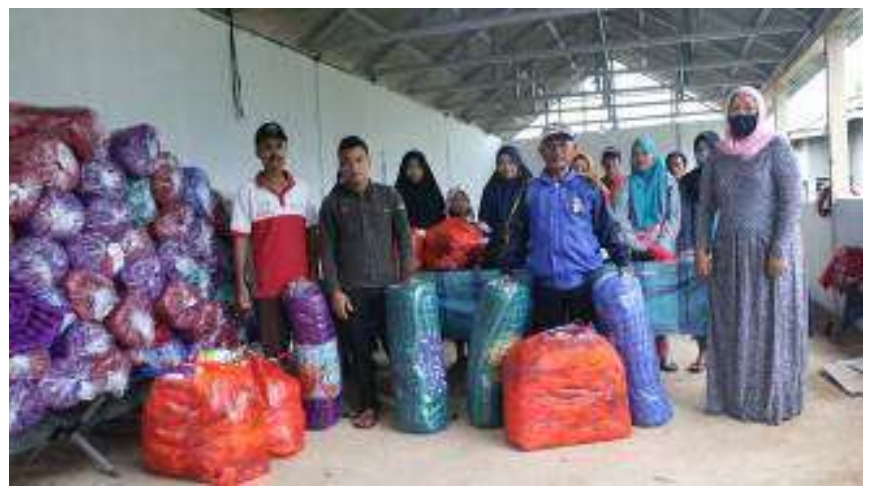

\section{Gambar 7. Foto tim menyerahakan sembako kepada warga.}

Pembagian sembako ini salah satu bukti rasa kepadulian kepada warga yang kehilangan barang-barang berharga pasca banjir. Selain itu untuk meringankan beban mereka dalam menghadapi musibah ini. Warga yang telah kehilangan harta benda khususnya tempat tidur (kasur) dan alat-alat dapur, mereka sangat membutuhkan dukungan dari semua pihak. Itu sebabnya para tim mengupayakan untuk menjadi kaki tangan bagi warga untuk menyalurkan sembako tersebut.

\section{Pembahasan}

Pelayanan dan bakti sosial yang dilakaukan oleh tim pengabdian masyarakat dan mahasiswa Sekolah Tinggi Teologi Real Batam adalah sebagai rasa wujud kemanusiaan atau kepedulian atas bencana alam yang menimpa masyarakat Tanjungpinang dan sekitarnya. Menurut Tambunan, dkk, 2020 bahwa bakti sosial atau lebih dikenal dengan baksos ini merupakan suatu kegiatan wujud dari kepedulian atau rasa kemanusiaan terhadap sesama manusia. Dimana dengan adanya kegiatan ini kita dapat merekatkan rasa kekerabatan kita terhadap orang lain. Kata sosial didalamnya tercakup perorangan dan kelompok kelompok (Tambunan, Purba, 2020). Selain itu, pelayanan dan bakti sosial ini sangat berarti kepada masyarakat karena merasa diperhatikan ditengah-tengah kesulitan yang sedang mereka alami.

Berdasarkan penjelasan itu maka dalam Aktivitas pelayanan dan bakti sosial yang dilakukan oleh tim pengabdian masyarakat, adalah sebagai berikut:

Pertama, mengumpulkan dan menyalamatkan ternak masyarakat. Menurut penjelasan masyarakat setempat bahwa pada saat banjir masyarakat tidak sempat menyelamatkan hewan peliharaan mereka karena banjir terlalu besar dan rumah serta kandang ternak ikut terendam banjir. Akibatnya ternak-ternak tersebut berkeliaran di luar. Dengan keadaan seperti ini maka tim dan mahasiswa berinisiatif untuk mengumpulkan dan menyelamatkan hewan-hewan tersebut agar tidak mencemari lingkungan dan mengganggu warga lain. Selain itu tim juga mencari makanan seadanya untuk hewan yakni batang pisang agar hewan-hewan ini tidak mati keparan dan terserang oleh penyakit. Masyarkat sangat 
berterimakasih kepada tim atas bantuannya sehingga ternak-ternak tersebut bisa kemabali ke kandang seperti semula.

Kedua, melakukan pengobatan gratis. Aktivitas lain yang dilakukan oleh tim adalah pengobatan gratis. Penanganan kesehatan masyarakat pasca banjir menjadi prioritas utama. Karena warga yang telah mengalami musibah banjir sangat mudah diserang oleh penyakit. Menurut tim kesehatan dari Sekolah Tinggi Teologi Real Batam mengatakan bahwa ada sejumlah penyakit yang rentan muncul selepas banjir, yakni diare, penyakit kulit/gatal-gatal dan demam berdarah. Widayatun menambahkan bahwa bencana alam akan menimbulkan berbagai permasalahan kesehatan bagi masyarakat terdampak khususnya bagi usia yang sudah lanjut (Widayatun \& Fatoni, 2013). Dengan melihat kondisi seperti ini maka tim dari pelayanan dan bakti sosial menerjunkan tenaga medis dan dokter untuk mengecek kesehatan seluruh warga yang mengalami musibah sebagai pertolongan pertama. Hal-hal yang siapkan oleh tim adalah menyiapkan perlengkapan medis, seperti obat-obatan dan APD serta meja dan kursi. Masyarakat sangat mengapresiasi pelayanan pengobatan ini karena warga yang dapat berobat serta mendapat Vitamin untuk menguatkan imun tubuh.

Ketiga, membuat dapur umum. Banyak warga yang mengungsi akibat dari dampak banjir yang menenggelamkan setiap rumah warga. Warga yang mengungsi ketempat yang lebih aman, mereka sangat membutuhkan pertolongan dari masyarakat lainnya khusus dalam hal makanan dan minum sehingga tim bergerak cepat untuk mendirikan dapur umum supaya warga yang mengalami musibah dari banjir ini tetap mendapatkan makanan selayaknya. Hal-hal yang dipersiapkan oleh tim pada saat itu adalah tenda, meja, kusi dan alat-alat dapur lainnya yang mendukung Aktivitas para tim di dapur untuk mempersiapkan makanan yang akan dibagi kepada seluruh warga. Aktivitas ini sangat menolong warga karena sebelumnya warga susah mendapatkan makan karena tempat tinggal mereka semua terendam banjir serta berapa ruas jalan putus dan longsor sehingga akses untuk mencari makan di luar sulit. Masyarakat sangat berterimakasih kepada tim atas kepedulian terhadap musibah yang mereka alami.

Keempat, menyiapkan air minum dan dapur air bersih tagana rajawali. Kebutuhan air minum dan air bersih sangat penting karena semua rumah warga terendam banjir sehingga sumur-sumur yang ada di warga tercemar dan kotor. Air bersih diperlukan oleh warga untuk keperluan sehari-hari seperti minum, mandi, memasak, mencuci dan sebagainya sehingga tim dari pengabdian ini menyiapkan dengan membuat dapur air bersih. Hal-hal yang disiapkan oleh tim di dapur air tagana rajawali ini adalah peralatan masak air dari listrik, air gallon dan tenda. Manfaat dari kegiatan ini adalah supaya para warga dan pasien yang hadir pada saat berobat dapat menikmati air tersebut sehingga mereka tidak merasa kehausan dan warga bisa dimanfatkan untuk keperluan keluarga. Warga senang atas kehadiran para 
tim pengabdian dari Sekolah Tinggi Teologi Real Batam karena kebutuhan yang mereka perlukan saat itu dapat tercukupkan.

Kelima, pembagian Sembako. Pembagian sembako ini merupakan salah satu dari perwujudan dan kepedulian untuk membantu kesejahteraan masyarakat yang terdampak banjir. Akibat lambatnya Pemerintah dalam menyalurkan bantuan kepada masyarakat yang terkena banjir, maka tim bergerak untuk mendata kebutuhan sejumlah warga diberbagai titik. Setelah tim mendapatkan data maka tim menyalurkan sembako tersebut kepada warga yang memerlukan, seperti kasur, selimut dan pakaian. Kebutuhan ini sangat dibuthkan oleh warga karena hampir semua rumah yang diterjang oleh banjir terendam banjir. Akibatnya semua peralatan rumah ikut rusak dan terendam, seperti kasur, selimut, baju dan alat dapur (tidak bisa digunakan).

\section{KESIMPULAN}

Kegiatan Pelayanan dan Bakti Sosial Pasca Banjir di Kota Tanjungpinang telah berjalan dengan baik sesuai dengan tujuan dari pengabdian masyarakat. Hasil kegiatan dari pengabdian masyarakat ini telah memberikan dapat positif, yakni meringankan beban masyarakat yang terdampak musibah banjir dan sebagian masyarakat kembali kerumahnya untuk melakukan Aktivitas sebagaimana penjelasan di atas. Sekalipun hasil ini masih belum sempurna, karena warga masih membutuhkan dukungan selanjutnya dalam membenahi tempat tinggalnya. Inisiatif dari tim pengabdian masyarakat ini sangat patut diapresiasi dan didukung penuh oleh para pimpinan dan dosen yang tergabung dalam tim pengabdian masyarakat dengan melakukan pendampingan sehingga kegiatan ini dapat terlaksana dengan baik.

\section{DAFTAR PUSTAKA}

A, R. N., \& Rahayu, S. (2014). Kajian Pemahaman Masyarakat Terhadap Banjir di Kelurahan Ulujami, Jakarta. Jurnal Teknik PWK, 3(2), 351-358.

Imamsari, F. S., Triastuti, R., \& Wijianto. (2017). Partisipasi Masyarakat Pada Penanggulangan Banjir Dalam Perspektif Pendidikan Kewarganegaraan. Educitizen, 2(1), 143-156.

Murdiyanto, \& Gutomo, T. (2015). Bencana Alam Banjir dan Tanah Longsor dan Upaya Masyarakat dalam Penanggulangan. Jurnal PKS, 14(4), 437-452.

Notoatmojo, S. (2005). Metodologi Penelitan Kesehatan. Jakarta: Rineka Cipta.

Sriharini. (2010). Membangun Masyarakat Sadar Bencana. Jurnal Dakwah, 11(2), 157-171.

Strauss, A., \& Corbin, J. (2003). Dasar-dasar Penelitian Kualitatif. Yogyakarta: Pustaka Pelajar.

Sugiyono. (2015). Metode Penelitian Kombinasi (Mix Methods). Bandung: Alfabeta.

Suryadi, N. (2020). Peran Pemerintah Dalam Menanggulangi Banjir Di Kota Samarinda. eJournal IImu Pemerintahan, 8(2), 425-436. 
Tambunan, E., Purba, M. L., \& ... (2020). Pendampingan Gerakan Bakti Sosial Berbagi Paket Sembako Peduli Covid-19 Hima Manajemen Universitas Sari Mutiara Indonesia. Jurnal Abdimas 1(September), 58-63.

Widayanti, S. Y. M. (2016). Sikap Sosial dan Partisipasi Masyarakat dalam Penanggulangan Bencana Alam Banjir. Jurnal PKS, 15(2), 145-164.

Widayatun, \& Fatoni, Z. (2013). Permasalahan Kesehatan dalam Kondisi Bencana:Peran Petugas Kesehatan dan Partisipasi Masyarakat (Health Problems in a Disaster Situation: the Role of Health Personnels and Community Participation). Jurnal Kependudukan Indonesia, 8(1), 37-52. 